\title{
Expression and distribution of galanin receptor subtypes in the rat carotid body
}

\author{
ANDREA PORZIONATO ${ }^{1}$, VERONICA MACCHI ${ }^{1}$, LUISA BARZON ${ }^{2}$, GIULIA MASI ${ }^{2}$, \\ ANNA BELLONI ${ }^{1}$, ANNA PARENTI ${ }^{3}$, GIORGIO PALÙ ${ }^{2}$ and RAFFAELE DE CARO ${ }^{1}$

\begin{abstract}
Department of ${ }^{1}$ Human Anatomy and Physiology, Section of Anatomy; ${ }^{2}$ Department of Histology, Microbiology and Medical Biotechnologies; ${ }^{3}$ Department of Medical Diagnostic Science and Special Therapies, Section of Pathologic Anatomy, University of Padua, I-35121 Padua, Italy
\end{abstract}

Received August 3, 2009; Accepted September 21, 2009

DOI: 10.3892/mmr_00000215

\begin{abstract}
Galanin is a 29 amino acid neuropeptide that is widely distributed in the nervous system and acts by binding to three $G$ protein-coupled receptors (GalR1, GalR2 and GalR3). In the literature, the presence of galanin has been reported in nerve fibers innervating the rat carotid body; however, direct evidence of the different galanin receptor subtypes expressed in carotid body cells has yet to be provided. In the present study, we investigated the presence and location of the three galanin receptor subtypes in 12 rat carotid bodies through real-time polymerase chain reaction (PCR) and immunohistochemistry. Real-time PCR identified GalR1 and GalR2 mRNA, with GalR2 gene expression being 100 times higher than that of the GalR1 gene. GalR3 mRNA was not detected. Statistically significant differences were not observed between the mean number of GalR1- and GalR2positive type I cells $(40.5 \pm 15.5$ vs. $37.1 \pm 13.2 \%)$. Anti-GalR3 immunohistochemistry did not identify positive cells in the carotid body. Type II cells were negative for the three galanin receptor subtypes. Our findings suggest that galanin may play a neuromodulator or trophic role in type I cells by binding to GalR1 and GalR2.
\end{abstract}

\section{Introduction}

Galanin is a 29 amino acid neuropeptide initially isolated from porcine intestine (1) and widely distributed in the central and peripheral nervous system. Galanin has been found to regulate many different functions in the central nervous system, such as energy and osmotic homeostasis, arousal/ sleep regulation, reproduction, nociception and cognition.

Correspondence to: Professor Raffaele De Caro, Department of Human Anatomy and Physiology, Section of Anatomy, University of Padua, Via A. Gabelli 65, I-35121 Padua, Italy

E-mail: rdecaro@unipd.it

Key words: galanin receptors, immunohistochemistry, carotid body
Three G protein-coupled receptors (GalR1, GalR2 and GalR3) have been identified (2-5). These show low sequence similarities, but are highly conserved between species (6). GalR1 and GalR2 show similar affinity towards galanin, whereas the affinity of GalR3 is lower (7). The three galanin receptor subtypes show distinct but overlapping expression patterns in the central and peripheral nervous system. GalR1 expression is higher in olfactory structures and subregions of the amygdala, thalamus, hypothalamus, pons, medulla and spinal cord. GalR2 shows the highest expression levels in the hippocampus (mainly dentate gyrus and CA3 field) and hypothalamus (supraoptic, arcuate and mammillary nuclei). GalR3 expression in the central nervous system is lower and mainly limited to the hypothalamus and areas of the mid- and hindbrain (7). Galanin-like peptide (GALP) is another endogenous ligand for galanin receptors that was originally identified in porcine hypothalamus and the gastrointestinal tract (8). Its gene shows a similar structural organization to the galanin gene. The binding affinity of GALP has been reported to be the highest for GalR3, followed by GalR2 (9).

The carotid body is a small ellipsoid tissue mass located at the carotid bifurcation. It is an arterial chemoreceptor that induces increases in ventilatory volume and frequency in response to hypoxia, hypercapnia, or reduction of blood $\mathrm{pH}$. The carotid body is organized in lobules separated by thin connective septa. The cells in these lobules are characterized as belonging to one of two different populations: type I (or chief) cells, with much cytoplasm and a few dendritic processes extending into extracellular spaces, and type II (or sustentacular) cells, fusiform in shape and located at the edges of the clusters $(10,11)$. Type I cells are considered the real chemoreceptor elements (chemoreceptor mechanisms reviewed in refs. 12-14) of the carotid body and release various neurotransmitters and neuromodulators in response to stimulation (reviewed in refs. 15-18). Chemosensory impulses are then mainly conveyed through glosso-pharyngeal afferent fibers arising from the petrosal ganglion. Type II cells show astrocytic markers and play a supportive role (11), although it has recently been noted that, when exposed to prolonged hypoxia, these cells may also behave as stem cell precursors for type I cells (19). The carotid body also shows sensory 
Table I. Genes and primers for real-time PCR analysis.

\begin{tabular}{llll}
\hline Gene & UPL Probe number & \multicolumn{1}{c}{ Primers } & Amplicon length (nt) \\
\hline Actb & 63 & F: ctggctcctagcaccatga & 76 \\
GalR1 & 46 & R: tagagccaccaatccacaca & 104 \\
GalR2 & 71 & F: tcagaggcatccaagaaaag & 61 \\
RalR3 & 38 & F: tccacttggtgataccatgaat & 82 \\
& R: tcctggctcgtgttctcc & \\
\hline
\end{tabular}

innervation from the jugular and nodose ganglia of the vagus, post-ganglionic sympathetic nerve fibers from the superior cervical ganglion, and preganglionic parasympathetic and sympathetic fibers reaching ganglion cells near the glomic cells (reviewed in ref. 20).

Galanin has been identified by immunohistochemistry in the nerve fibers of rat and chicken carotid bodies (20-27). In chicken carotid bodies, galanin-immunoreactive fibres have mainly been found to derive from the 14th cervical sympathetic ganglion. A portion of galanin-immunoreactive fibres have also been suggested to arise from intrinsic parasympathetic neurons (21-24). In the rat carotid body, most galaninimmunoreactive fibres are sensitive terminals originating from the petrosal ganglion (20,25-27). After transection of the carotid sinus nerve, the disappearance of galaninimmunoreactive nerve fibers and the acquisition of galanin immunoreactivity in originally immunonegative glomic cells and nerve fibers has been reported, probably originating from the superior cervical ganglion (25). In monkey and guinea-pig carotid bodies, galanin immunoreactivity has also been found in type I cells (28). To the best of our knowledge, the presence of the different galanin receptors has not yet been studied in carotid body structures. Thus, the aim of the present study was to investigate, through immunohistochemistry and realtime RT-PCR, the relative expression and distribution of the three galanin receptor subtypes in the rat carotid body, with particular reference to the different cellular populations.

\section{Materials and methods}

Tissue sampling and preparation. Materials consisted of carotid bodies obtained from 12 adult Sprague-Dawley rats weighing 200-250 g. Sampling of rats was performed soon after sacrifice. For immunohistochemistry, right carotid bifurcations were sampled, fixed in $4 \%$ paraformaldehyde for $1 \mathrm{~h}$, and then maintained in $30 \%$ sucrose overnight at $4^{\circ} \mathrm{C}$. Samples were then embedded in OCT compound and frozen by immersion in liquid nitrogen-cooled isopentane. Thick sections of $5 \mu \mathrm{m}$ were cut on a cryostat, mounted directly onto silane-coated slides, and maintained at $-80^{\circ} \mathrm{C}$ until immunohistochemical processing. For real-time PCR, left carotid bifurcations were dissected and the carotid bodies were cleaned from the surrounding tissues under a dissecting microscope, frozen immediately on dry ice and stored at $-80^{\circ} \mathrm{C}$.
Real-time PCR analysis. Total RNA was isolated from tissue samples using an RNeasy extraction kit (Qiagen $\mathrm{GmbH}$, Hilden, Germany). RNA was subjected to two treatments with DNA-free (Applied Biosystems/Ambion Austin, TX, USA) in order to remove any genomic DNA contamination, and random primed cDNAs were generated from $3 \mu \mathrm{g}$ of total RNA using MuLV reverse transcriptase (Applied Biosystems, Foster City, CA, USA). Quantitative real-time RT-PCR for genes encoding for $\beta$-actin and galanin receptors was performed using primers and probes designed with ProbeFinder for the Universal ProbeLibrary Set (Roche Diagnostics SpA, Monza, MI, Italy) (Table I). PCR amplifications were performed in duplicate under standard conditions using an ABI PRISM 7700 Sequence Detector System (Applied Biosystems). Relative quantification of transcripts was performed using the comparative 2- $\Delta \Delta \mathrm{CT}$ (threshold cycle) method (29).

Immunohistochemical analysis. Sections were incubated for 10 min with $0.01 \mathrm{M}$ phosphate buffer saline (PBS) containing $0.1 \%$ Triton $^{\circledR} \mathrm{X}-100$. Unmasking was performed with $10 \mathrm{mM}$ sodium citrate buffer, $\mathrm{pH} 6.0$, in a microwave oven at 900 watts. Primary antibody incubations were performed as follows: anti-GalR1 [goat polyclonal anti-GalR1 (C-20) sc-16216; Santa Cruz Biotechnology Inc., CA, USA] diluted 1:100 in blocking serum; anti-GalR2 [goat polyclonal antiGalR2 (K-20) sc-16219; Santa Cruz Biotechnology] diluted 1:50 in blocking serum; anti-GalR3 [goat polyclonal antiGalR3 (L-20) sc-16416; Santa Cruz Biotechnology] diluted 1:50 in blocking serum. Sections were then washed three times for 5 min in PBS, revealed with anti-goat serum (Vectastain Elite ABC kit Goat IgG PK-6105; Vector Laboratories Inc., Burlingame, CA, USA) for $30 \mathrm{~min}$ at room temperature and developed in 3,3'-diaminobenzidine (DAB; Sigma-Aldrich, Milan, Italy). Lastly, the sections were counterstained with hematoxylin. Negative controls were performed by the omission of primary antibody and through absorption tests. GalR immunoreactions detected in rat brain were used as positive controls.

The percentage of type I and II GalR-positive cells was evaluated at a magnification of 40x. Five sections and 3 fields per section were examined. The mean percentage of positive type I and II cells was calculated for each case and for the entire series. 

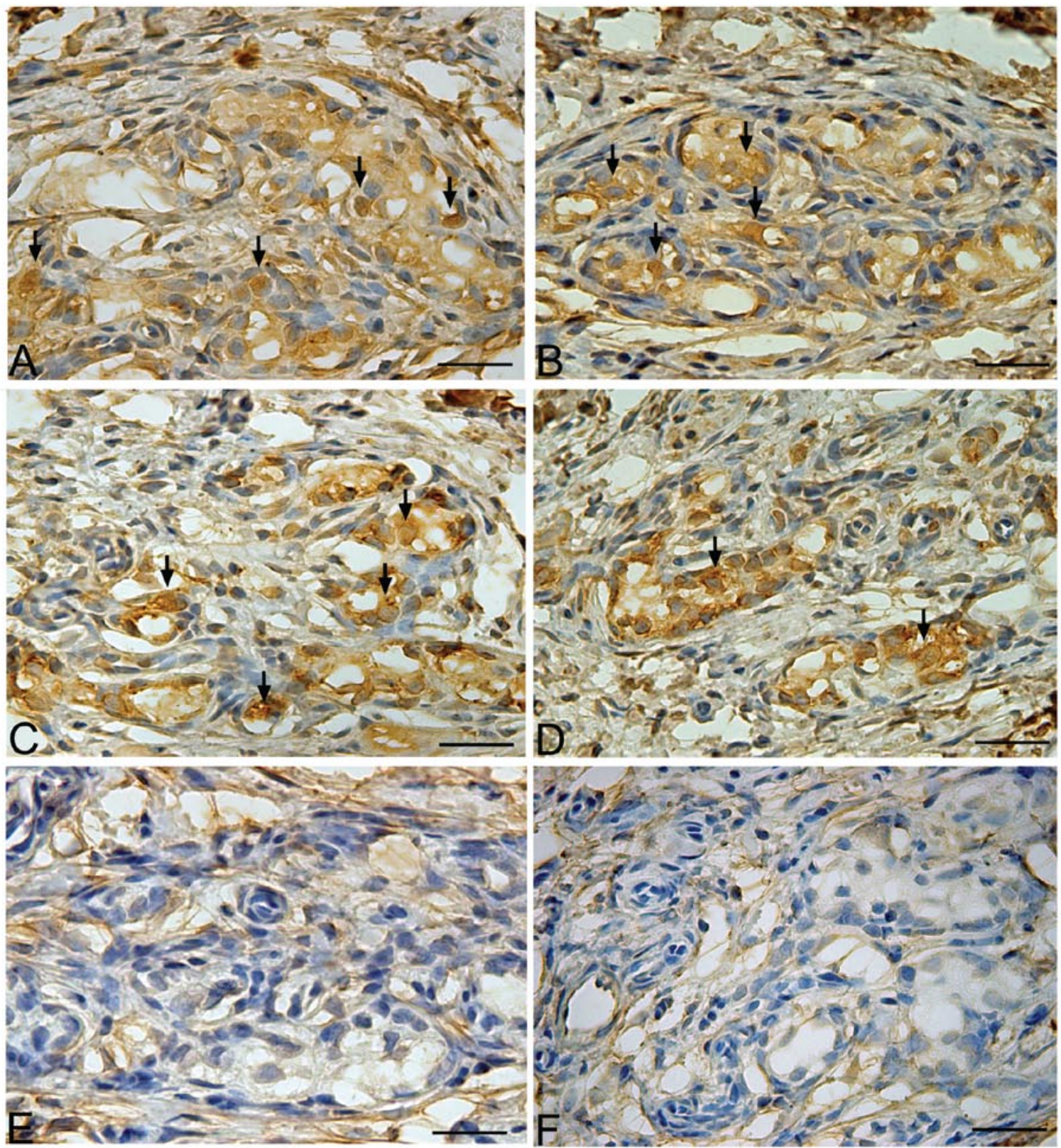

Figure 1. Immunohistochemistry for anti-GalR1 (A and B), anti-GalR2 ( $\mathrm{C}$ and D) and anti-GalR3 (E and F) showing immunopositive type I cells (arrows) for GalR1 and GalR2, and negativity for GalR3. Negative controls not shown. Scale bars, $24 \mu \mathrm{m}$.

Statistical analysis. Percentages obtained were compared using the Kruskal-Wallis test and Dunn's multiple comparison test. A P-value of 0.05 was considered significant.

\section{Results}

Immunohistochemistry revealed the presence of GalR1- and GalR2-positive type I cells, whereas all type I cells were negative for GalR3 immunostaining. Statistically significant differences were not found between the mean number of GalR1- and GalR2-positive type I cells $(40.5 \pm 15.5$ vs. $37.1 \pm 13.2 \%)$. Immunostained cells were distributed in the centre and the periphery of the lobules. No GalR1, GalR2 or GalR3 immunostaining was observed in type II cells (Fig. 1). Glomic cell immunostainings were eliminated when pre-absorbed antiserum was used or when primary antibodies were omitted.
PCR revealed the presence of GalR1 and GalR2 mRNA, but not GalR3 mRNA. Real-time PCR showed that GalR2 gene expression was approximately 100 times higher than that of the GalR1 gene.

\section{Discussion}

In the carotid body, glomic type I cells and sensitive and autonomic nerve fibres release numerous neurotransmitters and peptide neuromodulators, which play a role in the regulation of chemoreceptor discharge $(15-18,30,31)$. Circulating factors have also been reported to act on carotid body type I cells. For many of these neuromodulators, the specific receptor types expressed in type I cells are as yet unknown. To the best of our knowledge, this is the first study addressing the expression of galanin receptor types in type I cells. GalR1 and GalR2 were 
found to be expressed in type I cells using real-time PCR and immunohistochemistry. Immunohistochemistry did not reveal statistically significant differences between the percentage of GalR1- and GalR2-positive type I cells, whereas real-time PCR showed that GalR2 gene expression was approximately 100 times higher than that of the GalR1 gene. Such differences in the results obtained using the two methods may be due to the post-transcriptional regulatory mechanisms of protein synthesis or to the insufficient capability of immunohistochemistry to detect differences in the degree of receptor expression. Conversely, both immunohistochemistry and real-time PCR consistently failed to detect GalR3 expression. Our findings suggest that galanin plays different modulatory roles on chemoception by type I cells through two different receptors, GalR1 and GalR2. Regulation of the release of neurotransmitters and neuromodulators by galanin has previously been observed in the central and peripheral nervous systems $(32,33)$, and such action may also be hypothesized with regard to carotid body type I cells. Moreover, the binding of galanin to GalR1 and GalR2 is known to stimulate the phosphorylation of ERK and AKT (7), two signalling pathways known to be activated in the carotid body (34).

It is probable that galanin receptors in type I cells preferentially bind galanin that has been locally released in the carotid body. However, circulating blood galanin and GALP are also likely to modulate carotid body function by binding to GalR1 and GalR2. Galanin and GALP are involved in feeding and metabolism regulation. For example, GalR1-KO mice have been reported to exhibit impaired adaptation to an acute 3-day high-fat challenge, with increased food intake and weight gain (35). In mice, acute intracerebroventricular GALP infusion induces a decrease in food intake and body weight, and chronic GALP treatment produces a sustained decrease in body weight, although with the recovery of food intake (36). Evidence suggests that the effects of galanin and GALP on food intake and metabolism are mainly exerted via central actions in the hypothalamus (7). However, the idea that galanin and GALP could also peripherally modulate metabolism and feeding by binding to GalR 1 and GalR 2 in glomic type I cells is intriguing. In fact, the carotid body is also considered to play a role in glucose sensing and regulation (37-40), and it has been proposed that its role in glucose homeostasis is potentially mediated through the transduction of metabolically derived blood-borne factors (40). Analogously, central glucosensing neurons are known to respond not only to shortterm alterations in glucose availability, but also to long-term signals regarding energy homeostasis through the receptors for various peptides (including galanin and GALP) (41).

Galanin has also been observed to modulate neurogenesis, survival and the growth of different types of neurons in the central and peripheral nervous systems (42-45). Different trophic effects have been ascribed to different receptor types. For instance, due to its binding to GalR1 and GalR2/3, respectively, galanin shows antiproliferative effects on cultured neural stem cells and PC12 cell lines, while in the B104 neuroblastoma cell line it has proliferative action $(46,47)$. Galanin has also been demonstrated to modulate plasticity mechanisms in hippocampal CA1 neurons through the reduction of long-term potentiation (49). In the pre- and post-natal periods, the carotid body undergoes structural changes mediated by trophic factors. These include carotid body volume increase, the proliferation of type I, type II, endothelial and Schwann cells lining the peripheral nerve fibers, and an increased number of synapses between type I and II cells $(18,49)$. Environmental stimuli (for instance, hypoxic, hyperoxic or inflammatory noxae) may also cause a series of morphological, cellular and biochemical changes $(18,50,51)$. For instance, chronic hypoxia has been shown to increase $\mathrm{O}_{2}$ sensitivity in the carotid body through changes in molecular chemoreceptors, ion channels and neurochemicals (reviewed in refs. 52,53). The above changes are mediated by a wide series of trophic factors, and the presence of GalR1 and GalR2 on type I cells in addition to the ascertained role of galanin in cell survival and proliferation suggests a possible role for galanin in and of itself.

\section{Acknowledgements}

The authors are grateful to Gloria Sarasin and Anna Rambaldo for skillful technical assistance.

\section{References}

1. Tatemoto K, Rökaeus A, Jörnvall H, McDonald TJ and Mutt V: Galanin - a novel biologically active peptide from porcine intestine. FEBS Lett 164: 124-128, 1983.

2. Habert-Ortoli E, Amiranoff B, Loquet I, Laburthe M and Mayaux JF: Molecular cloning of a functional human galanin receptor. Proc Natl Acad Sci USA 91: 9780-9783, 1994.

3. Howard AD, Tan C, Shiao LL, Palyha OC, McKee KK, Weinberg DH, Feighner SD, Cascieri MA, Smith RG, van der Ploeg LH and Sullivan KA: Molecular cloning and characterization of a new receptor for galanin. FEBS Lett 405: 285-290, 1997.

4. Smith KE, Forray C, Walker MW, Jones KA, Tamm JA, Bard J, Branchek TA, Linemeyer DL and Gerald C: Expression cloning of a rat hypothalamic galanin receptor coupled to phosphoinositide turnover. J Biol Chem 272: 24612-24616, 1997.

5. Wang S, He C, Hashemi T and Bayne M: Cloning and expressional characterization of a novel galanin receptor. Identification of different pharmacophores within galanin for the three galanin receptor subtypes. J Biol Chem 272: 31949-31952, 1997.

6. Branchek TA, Smith KE, Gerald C and Walker MW: Galanin receptor subtypes. Trends Pharmacol Sci 21: 109-117, 2000.

7. Lang R, Gundlach AL and Kofler B: The galanin peptide family: receptor pharmacology, pleiotropic biological actions and implications in health and disease. Pharmacol Therapeut 115: 177-207, 2007.

8. Ohtaki T, Kumano S, Ishibashi Y, Ogi K, Matsui H, Harada M, Kitada C, Kurokawa T, Onda $\mathrm{H}$ and Fujino $\mathrm{M}$ : Isolation and cDNA cloning of a novel galanin-like peptide (GALP) from porcine hypothalamus. J Biol Chem 274: 37041-37045, 1999.

9. Lang R, Berger A, Santic R, Geisberger R, Hermann A, Herzog H and Kofler B: Pharmacological and functional characterization of galanin-like peptide fragments as potent galanin receptor agonists. Neuropeptides 39: 179-184, 2005.

10. Verna A: Ulstrastructure of the carotid body in the mammals. Int Rev Cytol 60: 271-330, 1979.

11. Pallot DJ: The mammalian carotid body. Adv Anat Embryol Cell Biol 102: 1-91, 1987.

12. Prabhakar NR: Oxygen sensing by the carotid body chemoreceptors. J Appl Physiol 88: 2287-2295, 2000.

13. Prabhakar $\mathrm{NR}: \mathrm{O}_{2}$ sensing at the mammalian carotid body: why multiple $\mathrm{O}_{2}$ sensors and multiple transmitters? Exp Physiol 91: 17-23, 2006.

14. López-Barneo J, Ortega-Sáenz P, Pardal R, Pascual A and Piruat JI: Carotid body oxygen sensing. Eur Respir J 32: 1386-1398, 2008.

15. Iturriaga $\mathrm{R}$ and Alcayaga $\mathrm{J}$ : Neurotransmission in the carotid body: transmitters and modulators between glomus cells and petrosal ganglion nerve terminals. Brain Res Brain Res Rev 47: 46-53, 2004.

16. Nurse CA: Neurotransmission and neuromodulation in the chemosensory carotid body. Auton Neurosci 120: 1-9, 2005. 
17. Shirahata M, Balbir A, Otsubo T and Fitzgerald RS: Role of acetylcholine in neurotransmission of the carotid body. Respir Physiol Neurobiol 157: 93-105, 2007.

18. Porzionato A, Macchi V, Parenti A and De Caro R: Trophic factors in the carotid body. Int Rev Cell Mol Biol 269: 1-58, 2008.

19. Pardal R, Ortega-Sáenz P, Durán R and López-Barneo J: Glia-like stem cells sustain physiologic neurogenesis in the adult mammalian carotid body. Cell 131: 364-377, 2007.

20. Ichikawa H: Innervation of the carotid body: immunohistochemical, denervation and retrograde tracing studies. Microsc Res Tech 59: 188-195, 2002.

21. Kameda Y: Distribution of CGRP-, somatostatin-, galanin-, VIPand substance P-immunoreactive nerve fibers in the chicken carotid body. Cell Tissue Res 257: 623-629, 1989.

22. Kameda Y: Ontogeny of the carotid body and glomus cells distributed in the wall of the common carotid artery and its branches in the chicken. Cell Tissue Res 261: 525-537, 1990.

23. Kameda Y: VIP-, galanin- and neuropeptide-Y-immunoreactive fibers in the chicken carotid bodies after various types of denervation. Cell Tissue Res 298: 437-447, 1999.

24. Kameda Y: Carotid body and glomus cells distributed in the wall of the common carotid artery in the bird. Microsc Res Tech 59: 196-206, 2002

25. Ichikawa $\mathrm{H}$ and Helke CJ: Distribution, origin and plasticity of galanin-immunoreactivity in the rat carotid body. Neuroscience 52: 757-767, 1993.

26. Ichikawa H, Rabchevsky A and Helke CJ: Presence and coexistence of putative neurotransmitters in carotid sinus baro- and chemoreceptor afferent neurons. Brain Res 611: 67-74, 1993.

27. Finley JC, Erickson JT and Katz DM: Galanin expression in carotid body afferent neurons. Neuroscience 68: 937-942, 1995.

28. Heym C and Kummer W: Immunohistochemical distribution and colocalization of regulatory peptides in the carotid body. J Electron Microsc Tech 12: 331-342, 1989.

29. Livak KJ and Schmittgen TD: Analysis of relative gene expression data using real-time quantitative PCR and the 2(-Delta Delta C(T)) Method. Methods 25: 402-408, 2001.

30. Porzionato A, Macchi V, Sandra Belloni A, Parenti A and De Caro R: Adrenomedullin immunoreactivity in the human carotid body. Peptides 27: 69-73, 2006.

31. Porzionato A, Macchi V, Amagliani A, Castagliuolo I, Parenti A and De Caro R: Neurotensin receptor 1 immunoreactivity in the peripheral ganglia and carotid body. Eur J Histochem (In press).

32. Fisone G, Wu CF, Consolo S, Nordström O, Brynne N, Bartfai T, Melander T and Hökfelt T: Galanin inhibits acetylcholine release in the ventral hippocampus of the rat: histochemical, autoradiographic, in vivo and in vitro studies. Proc Natl Acad Sci USA 84: 7339-7343, 1987.

33. Nordström O, Melander T, Hökfelt T, Bartfai T and Goldstein M: Evidence for an inhibitory effect of the peptide galanin on dopamine release from the rat median eminence. Neurosci Lett 73: 21-26, 1987.

34. Porzionato A, Macchi V, Parenti A and De Caro R: Extracellular signal-regulated kinase and phosphatidylinositol-3-kinase/AKT signalling pathways in the human carotid body and peripheral ganglia. Acta Histochem: Feb, 2009 (E-pub ahead of print).

35. Zorrilla EP, Brennan M, Sabino V, Lu X and Bartfai T: Galanin type 1 receptor knockout mice show altered responses to high-fat diet and glucose challenge. Physiol Behav 91: 479-485, 2007.

36. Krasnow SM, Fraley GS, Schuh SM, Baumgartner JW, Clifton DK and Steiner RA: A role for galanin-like peptide in the integration of feeding, body weight regulation and reproduction in the mouse. Endocrinology 144: 813-822, 2003.
37. Alvarez-Buylla R and De Alvarez-Buylla ER: Carotid sinus receptors participate in glucose homeostasis. Respir Physiol 72: 347-359, 1988.

38. Koyama Y, Coker RH, Stone EE, Lacy DB, Jabbour K, Williams PE and Wasserman DH: Evidence that carotid bodies play an important role in glucoregulation in vivo. Diabetes 49: 1434-1442, 2000.

39. Pardal R and López-Barneo J: Low glucose-sensing cells in the carotid body. Nat Neurosci 5: 197-198, 2002.

40. Bin-Jaliah I, Maskell PD and Kumar P: Indirect sensing of insulin-induced hypoglycaemia by the carotid body in the rat. J Physiol 556: 255-266, 2004.

41. Levin BE: Glucosensing neurons do more than just sense glucose. Int J Obes Relat Metab Disord 25: 68-72, 2001.

42. Holmes FE, Mahoney S, King VR, Bacon A, Kerr NC, Pachnis V, Curtis R, Priestley JV and Wynick D: Targeted disruption of the galanin gene reduces the number of sensory neurons and their regenerative capacity. Proc Natl Acad Sci USA 97: 11563-11568, 2000.

43. O'Meara G, Coumis U, Ma SY, Kehr J, Mahoney S, Bacon A Allen SJ, Holmes F, Kahl U, Wang FH, Kearns IR, Ove-Ogren S, Dawbarn D, Mufson EJ, Davies C, Dawson G and Wynick D: Galanin regulates the postnatal survival of a subset of basal forebrain cholinergic neurons. Proc Natl Acad Sci USA 97: 11569-11574, 2000.

44. Shen PJ, Larm JA and Gundlach AL: Expression and plasticity of galanin systems in cortical neurons, oligodendrocyte progenitors and proliferative zones in normal brain and after spreading depression. Eur J Neurosci 18: 1362-1376, 2003.

45. Elliott-Hunt CR, Marsh B, Bacon A, Pope R, Vanderplank P and Wynick D: Galanin acts as a neuroprotective factor to the hippocampus. Proc Natl Acad Sci USA 101: 5105-5110, 2004.

46. Shen PJ, Yuan CG, Ma J, Cheng S, Yao M, Turnley AM and Gundlach AL: Galanin in neuro(glio)genesis: expression of galanin and receptors by progenitor cells in vivo and in vitro and effects of galanin on neurosphere proliferation. Neuropeptides 39: 201-205, 2005.

47. Cheng $\mathrm{S}$ and Yuan CG: Differential effect of galanin on proliferation of PC12 and B104 cells. Neuroreport 18: 1379-1383, 2007.

48. Badie-Mahdavi H, Lu X, Behrens MM and Bartfai T: Role of galanin receptor 1 and galanin receptor 2 activation in synaptic plasticity associated with 3',5'-cyclic AMP response elementbinding protein phosphorylation in the dentate gyrus: studies with a galanin receptor 2 agonist and galanin receptor 1 knockout mice. Neuroscience 133: 591-604, 2005.

49. Porzionato A, Macchi V, Parenti A, Matturri L and De Caro R: Peripheral chemoreceptors: postnatal development and cytochemical findings in Sudden Infant Death Syndrome. Histol Histopathol 23: 351-365, 2008.

50. Porzionato A, Macchi V, Guidolin D, Parenti A, Ferrara SD and De Caro R: Histopathology of carotid body in heroin addiction. Possible chemosensitive impairment. Histopathology 46: 296-306, 2005.

51. Porzionato A, Macchi V, Parenti A and De Caro R: Chronic carotid glomitis in heroin addiction. Histol Histopathol 24: 707-715, 2009.

52. Prabhakar NR and Jacono FJ: Cellular and molecular mechanisms associated with carotid body adaptations to chronic hypoxia. High Alt Med Biol 6: 112-120, 2005.

53. Powell FL: The influence of chronic hypoxia upon chemoreception. Respir Physiol Neurobiol 157: 154-161, 2007. 